\title{
En kvinne i 50-årene med nakkesmerter og forhøyet senkningsreaksjon
}

\author{
Både nakkesmerter og uspesifikke infeksjonssymptomer er vanlig \\ i allmennpraksis. Sykdomsbildet hos den aktuelle pasienten var til \\ å begynne med diffust, men etter en noe forsinket utredning identifi- \\ serte vi en sjelden tilstand med høy risiko for alvorlige nevrologiske \\ sekveler og plutselig død.
}

En kvinne i 50-årene ble innlagt på lokalsykehuset etter at hun seks uker tidligere hadde fått akutte nakkesmerter med utstråling mot halsmuskler fortil i forbindelse med fysisk aktivitet. Hun hadde også hatt pressfølelse og stikkende følelse i tungen, svelgevansker og følelse av tranghet $i$ halsen, men ingen feber. Blodprøver tatt hos fastlegen to uker før innleggelse viste senkningsreaksjon (SR) på $86 \mathrm{~mm}(3-28 \mathrm{~mm})$ og $\mathrm{Hb} 9,7 \mathrm{~g} /$ $100 \mathrm{ml}(11,5-16 \mathrm{~g} / 100 \mathrm{ml}$. Hun anga et vekttap på 3-4 kg på en måned.

Kvinnen var frisør og hadde kroniske muskel-og skjelettplager i nakken. Før det aktuelle hadde hun vært behandlet for dette hos kiropraktor og fysioterapeut. MR av cervikalcolumna tre måneder før det aktuelle var uten patologiske funn. Ett år tidligere hadde hun fått gjennomført diatermi av neseslimhinne på venstre side på grunn av neseblødningstendens.

Hun ble innlagt for medisinsk utredning på grunn av langvarig og uavklart, antatt alvorlig tilstand. Ved innleggelsen hadde hun svelgevansker og redusert matlyst. Hun var i god allmenntilstand og afebril. Man fant ved ørenese-hals-undersøkelse en neseseptumperforasjon, men ellers normale funn. C-reaktivt protein (CRP) var $85 \mathrm{mg} / \mathrm{l} /<5 \mathrm{mg} / \mathrm{ll}$. Blodkulturer viste ingen oppvekst. Som ledd i utredningen, og på grunn av hennes nevrologiske symptomer, ble det dagen etter innleggelsen rekvirert CT av collum og thorax samt MR av collum. Disse undersøkelsene viste destruksjon av atlasbuene og dens axis, med betydelig omkringliggende bløtdelshevelse og innsnevring av spinalkanalen med kompresjon av medulla (fig 1).

Funn ved CT- og MR-undersøkelsene kunne være forenlig med ondartet sykdom, uttalt artritt eller lokalisert infeksjon. Destruksjon av øvre cervikalcolumna ville kunne gi en ustabil nakke med risiko for økende nevrologiske symptomer.

Hun hadde ingen klare nevrologiske utfall. Røntgenbildene ble vurdert av spesialist $i$ revmatologi, som konkluderte med at sannsynligheten for revmatologisk sykdom var liten. Etter å ha konferert med nevrokirurg startet man behandling med metylprednisolon $32 \mathrm{mg} \times 2$ for å dempe lokal inflammasjon og bedre plassforholdene i spinalkanalen. Hun fikk tilpasset stiv nakkekrage og ble overført til universitetssykehus med nevrokirurgisk kompetanse.

I mangel av diagnostisk avklaring ble pasienten vurdert av øre-nese-hals-spesialist for prøvetaking fra lokale forandringer øverst i cervikalcolumna.

Åtte dager etter første innleggelse ble det $i$ narkose høstet biopsimateriale og dyrkingsprøver fra prevertebralt område ved C1-C2. Prøvetaking ble gjort via vertikal incisjon gjennom slimhinne og ligamentum longitudinale anterius. Inngrepet ble gjennomført transnasalt under endoskopisk veiledning (fig 2). Frysesnittundersøkelse og senere endelig histologi viste ikke tegn til malignitet, kun inflammatoriske forandringer med innslag av kalk eller beinrester (fig 3). Svar på dyrking fra prevertebralt område, $i$ tre forskjellige prøver, viste penicillinresistente Staphylococcus aureus.

På grunn av forholdene rundt prøvetaking og vurdering av radiologiske, histologiske og mikrobiologiske funn ble histologi og dyrkingssvar vurdert som representative. Antibiotikabehandling ble iverksatt etter svar på frysesnittundersøkelsen, samme dag som biopsi ble tatt.

Hun fikk intravenøs cefotaksim $1 \mathrm{~g} \times 3$ og kloksacillin $2 g \times 4$. Dette ble senere endret til klindamycin $600 \mathrm{mg} \times 3$ og fusidin $500 \mathrm{mg} \times 3$ på grunn av hudreaksjoner. Hun viste klinisk, laboratoriemessig og radiologisk bedring og ble utskrevet i god allmenntilstand til lokalsykehus tre uker etter første innleggelse for fortsatt intravenøs antibiotikabehandling og nedtrapping av metylprednisolon. Hun beholdt nakkekragen i ni måneder, inntil man

\author{
Niels Christian Stenklev \\ niels.christian.stenklev@unn.no \\ Fagområdet øre-nese-hals \\ Nevro- og ortopediklinikken \\ Universitetssykehuset Nord-Norge \\ og \\ $\emptyset$ re-nese-hals-seksjonen \\ Institutt for klinisk medisin \\ Universitetet i Troms $\varnothing$ \\ Harald Rusten \\ Fagområdet øre-nese-hals \\ Nevro- og ortopediklinikken \\ Universitetssykehuset Nord-Norge

\section{Kay Müller}

\section{Rune Hennig} \\ Fagområdet nevrokirurgi \\ Nevro- og ortopediklinikken \\ Universitetssykehuset Nord-Norge \\ og \\ Institutt for klinisk medisin \\ Universitetet i Troms $\varnothing$

\section{Tormod Eggen} \\ Avdeling for klinisk patologi \\ Gry Wikran \\ Radiologisk avdeling \\ Diagnostisk klinikk \\ Universitetssykehuset Nord-Norge
}

> Se kommentar side 343 


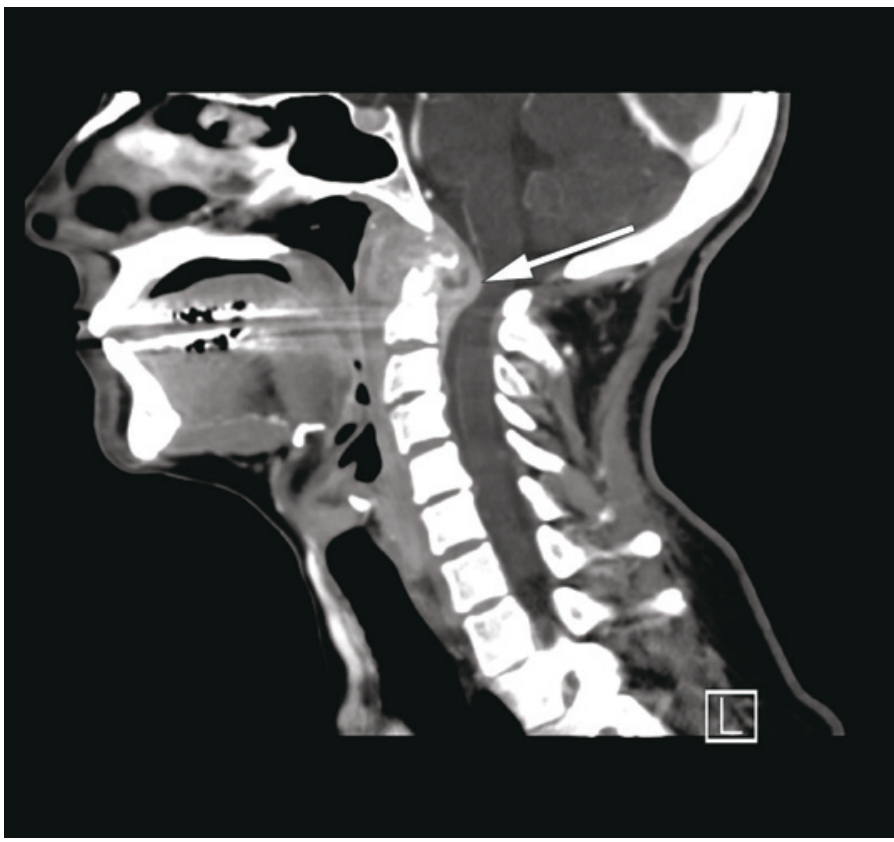

Figur 1 Første CT av cervikalcolumna viser betydelig bløtdelshevelse og kontrastoppladning prevertebralt og epiduralt omkring C1-C2 (pil), med kompresjon av medulla. Begynnende destruksjon av dens.

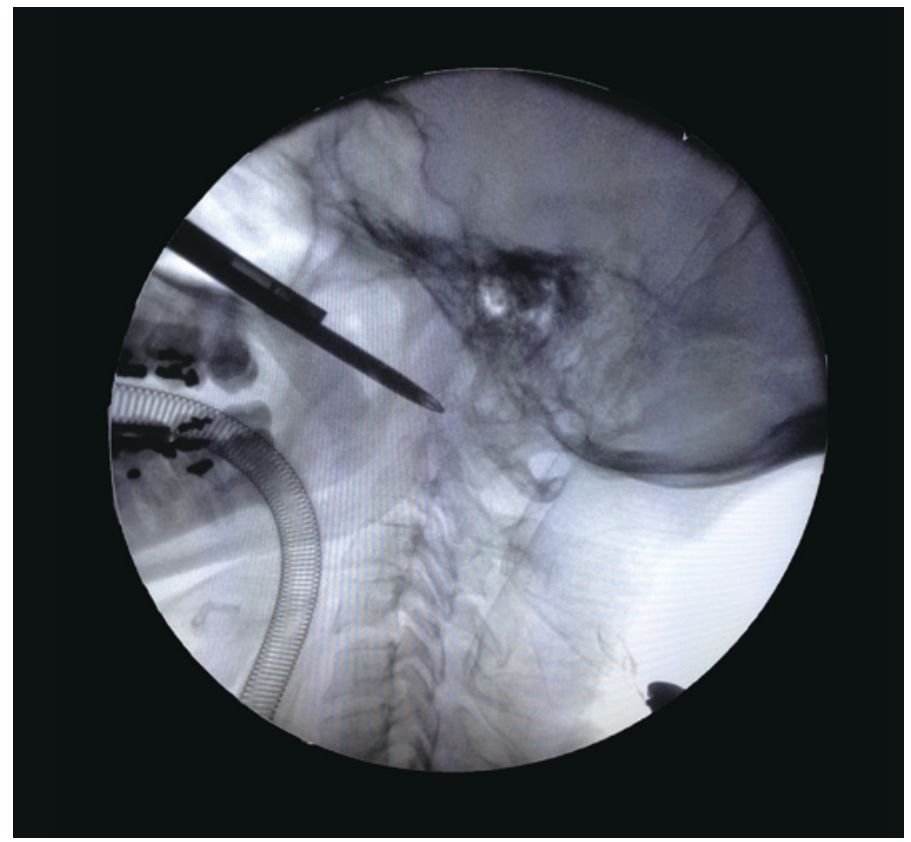

Figur 2 Endoskopisk biopsitaking av prevertebralt område med Weils tang i nivå med fremre atlasbue. Bildet er tatt med gjennomlysning

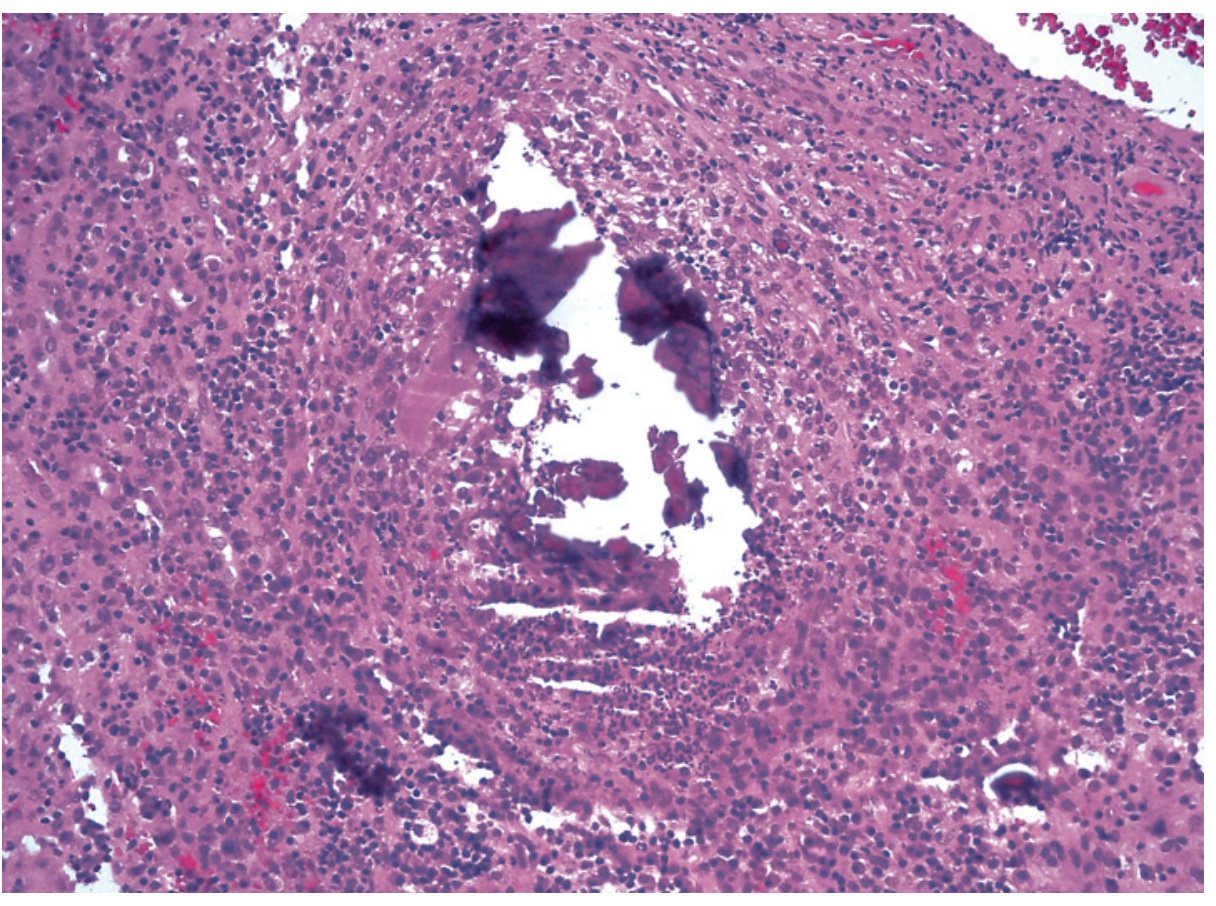

Figur 3 Hematoksylin-eosin-farget histologisk preparat fra prevertebralt område. Snittet viser innslag av kronisk betennelse, fremmedlegemereaksjon og områder med kalk. Det er ikke tegn til malignitet

vurderte at hun hadde utviklet en stabil ankylose av kraniocervikal overgang. Antibiotikabehandling ble gitt itil sammen fire måneder. Etter avsluttet forløp hadde pasienten lite smerter. Hun hadde innskrenket bevegelighet av nakken og ble fulgt videre med fysikalsk behandling. sykdomsfølelse og vekttap. Etter hvert kan det tilkomme økende smerter opp mot bakhodet og nevrologiske utfall (2). Vår pasient fikk en relativt tidlig diagnose på grunn av funn ved CT- og MR-undersøkelsene. Tidlig diagnostikk er vanskelig, og konsekvensene av forsinket diagnose og behandling kan være alvorlige. Tilstanden medfører destruksjon av columna og vevsekspansjon inn mot hjernestamme og ryggmarg, med risiko for tverrsnittslesjon, respirasjonsstans og plutselig død. Ved fatalt forløp er det usikkert om korrekt dødsårsak vil erkjennes, da øvre cervikalcolumna ikke rutinemessig omfattes av obduksjon.

I litteraturen benevnes dette sykdomsbildet som spondylodiskitt, spondylitt eller osteomyelitt av første og andre nakkevirvel. Da det ikke finnes mellomvirvelskive mellom $\mathrm{C} 1$ og $\mathrm{C} 2$, og begge virvler vanligvis er angrepet, mener vi det er mest korrekt å kategorisere denne tilstanden som akutt hematogen spondylitt i C1-C2. Det finnes holdepunkter for at rundt halvparten av tilfellene er forårsaket av S. aureus (3). Mulig primærfokus for hematogen spredning av $\mathrm{S}$. aureus kan da identifiseres i noen, men ikke alle, tilfellene (3). Pasienten vår hadde bestående perforasjon av neseseptum, sannsynligvis etter tidligere elektrokoagulering av neseseptum. Man kan mistenke at kolonisering med kronisk lavgradig inflammasjon her kan ha medført hematogen spredning av S. aureus. Tuberkuløs spondylitt er fortsatt en viktig differensialdiagnose ved akutt spondylitt i C1-C2 (4), også i vårt land, selv 
om det nok var mer vanlig i tidligere tider. Klinisk forløp ved tuberkuløs spondylitt i $\mathrm{C} 1-\mathrm{C} 2$ beskrives som mer langvarig og subakutt enn ved akutte infeksjoner av ikkegranulomatøs type. Vår pasient hadde et relativt akutt forløp, der funn ved utredning og effekt av behandlingen bekreftet mistanken om akutt hematogen spondylitt av ikkegranulomatøs type.

Differensialdiagnostisk er det i begynnelsen av det kliniske forløpet vanskelig å skille akutt hematogen spondylitt fra ondartet sykdom eller revmatoid inflammasjon med destruksjon av $\mathrm{C} 1-\mathrm{C} 2$. Aagaard og medarbeidere fant at blodkultur var positiv i rundt $70 \%$ av tilfellene (3). Biopsitaking og dyrkningsprøve fra prevertebralt område er likevel ønskelig for å øke den diagnostiske presisjonen. Det er påkrevd med rask diagnostisering, da forsinkelse kan gi livstruende komplikasjoner (5). Spesialister i øre-nesehals-sykdommer, i nevrokirurgi og i radiologi er sentrale i diagnostikk av denne tilstanden. Prøvetaking fra prevertebralt område gjøres best fra pharynx, gjennom en transnasal eller transoral tilgang (6). Behandling er i første rekke konservativ, med stiv nakkekrage og langvarig antibiotikabehandling. Ved radiologisk progrediering eller økende nevrologiske symptomer må kirurgisk dekompresjon og eventuell fiksasjon vurderes (3).

\section{Oppsummering}

Vi beskriver en pasient med akutt hematogen spondylitt i $\mathrm{C} 1-\mathrm{C} 2$. Denne sjeldne og livstruende tilstanden kan mistenkes ved akutte og svært kraftige smerter i øvre del av nakken eller bakhodet, dersom pasienten $\mathrm{i}$ tillegg har infeksjonssymptomer og nedsatt allmenntilstand med vekttap, og spesielt ved nevrologiske følgesymptomer. CT eller MR av cervikalcolumna er nødvendig for å stille diagnosen og bør vurderes ved slike symptombilder.

Pasienten har samtykket til at artikkelen blir publisert.

Forfatterne takker Tore Wold, Universitetssykehuset Nord-Norge, Harstad for kommentarer knyttet til CT cervikalcolumna (figur 1).

\section{Niels Christian Stenklev (f. 1964)}

er dr.med., spesialist i øre-nese-halssykdommer, med spesialkompetanse i nese- og mellomørekirurgi, overlege og førsteamanuensis. Forfatter har fylt ut ICMJE-skjemaet og oppgir ingen interessekonflikter.

\section{Harald Rusten (f. 1980)}

er lege i spesialisering i øre-nese-halssykdommer.

Forfatter har fylt ut ICMJE-skjemaet og oppgir ingen interessekonflikter.

\section{Kay Müller (f. 1969)}

er ph.d., spesialist i nevrokirurgi, overlege og førsteamanuensis.

Forfatter har fylt ut ICMJE-skjemaet og oppgir ingen interessekonflikter.

\section{Rune Hennig (f. 1952)}

er spesialist i nevrokirurgi, overlege og professor Forfatter har fylt ut ICMJE-skjemaet og oppgir ingen interessekonflikter.

\section{Tormod Eggen (f. 1967)}

er ph.d. og spesialist i patologi. Forfatter har fylt ut ICMJE-skjemaet og oppgir ingen interessekonflikter.

\section{Gry Wikran (f. 1969)}

er spesialist i radiologi, med spesialkompetanse i nevro- og øre-nese-hals-radiologi. Forfatter har fylt ut ICMJE-skjemaet og oppgir ingen interessekonflikter.

Litteratur

1. Schimmer RC, Jeanneret C, Nunley PD et al. Osteomyelitis of the cervical spine: a potentially dramatic disease. J Spinal Disord Tech 2002; 15: $110-7$

2. Wiedau-Pazos M, Curio G, Grüsser C. Epidural abscess of the cervical spine with osteomyelitis of the odontoid process. Spine 1999: 24: 133-6.

3. Aagaard T, Roed C, Dragsted C et al. Microbiological and therapeutic challenges in infectious spondylodiscitis: a cohort study of 100 cases, 2006-2011. Scand J Infect Dis 2013; 45: 417-24.

4. Mishra S, Srivastava AK, Singh DK et al. Rescuing the falling head. Neurol India 2013; 61: 332-3.

5. Parish DC, Clark JA, Liebowitz SM et al. Sudden death in rheumatoid arthritis from vertical subluxation of the odontoid process. J Natl Med Assoc 1990; 82: 297-9, 302-4

6. Lee A, Sommer D, Reddy K et al. Endoscopic transnasal approach to the craniocervical junction. Skull Base 2010; 20: 199-205.

Mottatt 11.8. 2014, første revisjon innsendt 6.10. 2014, godkjent 5.1. 2015. Redaktør: Siri Lunde Strømme.

\section{Kommentar}

\section{En uvanlig årsak til ryggsmerter}

Stenklev og medarbeidere presenterer historien til en pasient med osteomyelitt i øvre cervikalcolumna. Denne lokalisasjonen er sjelden og kan føre til tverrsnittslesjon og plutselig død. Pasienten hadde kroniske muskel- og skjelettplager fra nakken før det aktuelle og var utredet med MR av nakken tre måneder før hun ble akutt syk. Diagnosen ble allikevel stilt relativt raskt, og pasienten unngikk alvorlige komplikasjoner. Sykehistorien har flere relevante diagnostiske og terapeutiske poenger.

På et fastlegekontor ser man sjelden infeksjoner i columna, mens nakke- og ryggsmerter er vanlige. Det kan derfor være vanskelig å mistenke osteomyelitt, også fordi tilstanden oftest begynner snikende og progredierer over uker og måneder. I en studie var mediantiden fra symptomdebut til diagnosen $48 \pm 40$ dager (1). Smertene kan forverres om natten, men kan også initialt lindres ved sengeleie. Feber et angitt hos opp til $50 \%$ av pasientene, men mange pasienter med ryggsmerter får ikke-steroide antiinflammatoriske midler (NSAID-preparater) som kan kamuflere feber (2). Hvis tilstanden kompliseres av epidural abscess, kan det komme nevrologiske utfall, eventuelt med pareser. Ved klinisk undersøkelse kan det være bankeømhet over processus spinosus i det smertefulle området. Hvis det også er forhøyede inflammasjonsparametere, bør det lede tanken hen på osteomyelitt.

Et annet diagnostisk poeng er at vanlig røntgen gir negative funn de første 2-3 ukene etter sykdomsdebut, og skjelettscintigrafi har lav spesifisitet. Ved mistanke om osteomyelitt bør man foretrekke MR, da eventuelle bløtdelsinfeksjoner som abscesser fremstilles bedre enn ved CT (3).

Fordi antibiotikabehandlingen er langvarig og vanskelig, er det imperativt å finne agens. Blodkulturer skal tas før antibiotikabehandling. Hvis disse viser oppvekst av typiske osteomyelittbakterier som Staphylo- 